\title{
INFLUENCE OF POST-BLEACHING TIME INTERVALS USING 37\% CARBAMIDE PEROXIDE ON DENTAL SUBSTRATE ADHESION
}

\author{
Shelyn Akari Yamakami* \\ Juliana Jendiroba Faraoni' \\ Daniela Pires Caslini ${ }^{\star \star *}$ \\ Michelle Alexandra Chinelatti ${ }^{*+* x}$ \\ Regina Guenka Palma-Dibb
}

\begin{abstract}
The aim of this study was to evaluate the influence of post-bleaching time intervals using $37 \%$ carbamide peroxide on dental substrate adhesion. Fifty bovine incisors were sectioned in two groups of $4 \mathrm{X} 4 \mathrm{~mm}$ standard blocks to obtain 50 specimens in each group $(n=50)$. In fifty blocks, the dentin (D) was analyzed and in the other 50 the enamel (E). Blocks were subjected to bleaching treatment and restored with Single Bond/ z250 according to post-bleaching time intervals $(0,7,14$ and 21 days). Twenty-four hours after adhesive/resin cylinders on substrate confection, shear bond strength test (SBS) was performed in an universal test machine. Means in MPa and their respective standard deviations were: $\mathrm{E}$ - control: 31.89 (2.39); T0: 19.07 (2.00); T7: 24.97 (4.89); T14: 29.71 (4.89); T21: 40.91 (4.75) and D - control: 18.90 (3.64); T0: 2.22 (0.41); T7: 3.79 (0.75); T14: 5.95 (0.79); T21: 8.40 (0.87). Data were submitted to ANOVA and Tukey $(p<0.05)$ tests. The bond strength value for the enamel was statistically higher than the dentin, and both were lower than the control group that had similar results after 21 days post-bleaching. In dentin group, the control showed superior bond strength and was statistically different in relation to other times. It was concluded that bleaching had negative influence on adhesion. Therefore it is necessary to wait, at least, 21 days after bleaching to restore the enamel.
\end{abstract}

KEYWORDS: Bleaching Agents; Peroxides; Dentin; Enamel.

\section{AVALIACÃO IN VITRO DA INFLUÊNCIA DE DIFERENTES INTERVALOS DE TEMPO PÓS- CLAREAMENTTO COM PERÓXIDO DE CARBAMIDA 37\% NA ADESÃO AO SUBSTRATO DENTAL}

\begin{abstract}
: 0 objetivo deste estudo foi avaliar a influência do peróxido de carbamida a 37\% sobre a adesão dos substratos dentários em diferentes intervalos de tempo pós-clareamento. Cinquenta incisivos bovinos foram divididos em dois grupos de blocos padrão $4 \times 4 \mathrm{~mm}$ para obter 50 espécimes de cada grupo $(\mathrm{n}=50)$. Em cinquenta blocos, a dentina (D) foi analisada e nos outros 50 o esmalte (E). Os blocos foram submetidos ao tratamento de clareamento e restaurados com Single Bond/z250 de acordo com os intervalos de tempo pósclareamento $(0,7,14$ e 21 dias). Após vinte e quatro horas os corpos de prova preparados com adesivo/resina foram submetidos ao teste de resistência ao cisalhamento (SBS) em uma máquina universal de ensaio. As médias (Mpa) e seus respectivos desvios padrão foram: $\mathrm{E}$ - controle: 31,89 (2,39); T0: 19,07 (2,00); T7: 24,97 (4,89); T14: 29,71 (4,89); T21: 40,91 (4,75) e D - controle: 18,90 (3,64); T0: 2,22 (0,41); T7: 3,79 (0,75); T14: 5,95 (0,79); T21: $8,40(0,87)$. Os dados foram submetidos à ANOVA e ao teste de Turkey $(p<0,05)$. 0 valor da resistência de união para 0 esmalte foi estatisticamente superior a dentina e ambos foram inferiores ao grupo controle que apresentou resultados semelhantes após 21 dias pós-branqueamento. 0 grupo controle (D) apresentou valores de resistência de união superior e estatisticamente diferente em relação aos outros tempos. Concluiu-se que 0 clareamento teve influência negativa sobre a adesão. Portanto, tornar-se-á necessário aguardar, pelo menos, 21 dias após 0 clareamento para restaurar 0 esmalte.
\end{abstract}

KEYWORDS: Clareadores; Peróxidos; Dentina; Esmalte Dentário.

\footnotetext{
* Restorative Dentistry Department, Ribeirão Preto Dental School, University of São Paulo (USP), Brasil.

${ }^{* *}$ Restorative Dentistry Department, Ribeirão Preto Dental School, University of São Paulo (USP), Brasil

${ }^{* * * *}$ Restorative Dentistry Department, Ribeirão Preto Dental School, University of São Paulo (USP), Brasil

${ }^{* * * *}$ Restorative Dentistry Department, Ribeirão Preto Dental School, University of São Paulo (USP), Brasil

${ }^{* * * * *}$ Restorative Dentistry Department, Ribeirão Preto Dental School, University of São Paulo (USP), Brasil
} 
Clinical Relevance: Bleaching treatment for non-vital teeth with $37 \%$ carbamide peroxide can negatively influence composite resin adhesion, and it is necessary to wait, at least, 21 days after bleaching to restore dental structure.

\section{INTRODUCTION}

Discoloration of teeth is a factor that compromise esthetics. However, this problem can be treated through the bleaching procedure, which can turn it minimal or even return the color to the tooth (FERREIRA, 2016). Nowadays, bleaching agents with hydrogen peroxide, as their active substance, have been chosen in clinical field because their action mechanism consists of a strong oxidation reaction through the formation of free radicals, reactive oxygen molecules and peroxide anions of hydrogen (CHNG, 2002; EIMAR, 2012; XU, 2011). These reactive molecules attack the long-chained, dark-colored chromophore molecules of the tooth and split them into smaller, less colored and more diffusible molecules (TREDWIN, 2006). Carbamide peroxide, a material hitherto used for extern bleaching, has been indicated for inner bleaching and has obtained satisfactory results. It is applied in the pulp chamber by means of a technique known as walking bleach, an efficient technique that requires less time spent and avoids more costly and invasive dental treatments, besides the preservation of the dental structure (SPASSER, 1961).

The bleaching materials used in the walking bleach technique have an active substance, hydrogen peroxide, which is responsible for tooth bleaching (SPASSER, 1961). Although hydrogen peroxide remains active within the pulp chamber and in dentin tubules for a significant period after bleaching, it releases more oxygen resulting from its decomposition, which can reduce the adhesion of restorative materials after the application of bleaching procedure (BERGER, 2013; CANNABRAVA, 2014).

Therefore, tooth pretreatment using hydrogen peroxide-based substances may affect the quality of adhesion of restorative materials. Thus, the residual oxygen can inhibit resin polymerization and, as a result, decrease the bond strength of the restorative material (GAUTHIER, 2005; BARCELLOS, 2010). Besides, a marginal microinfiltration increasing may occur due to defective marginal closure (KUMAR, 2015).

To control the adverse effect of the bleaching treatment, it was suggested to increase the waiting time between the procedure and the subsequent restoration for oxygen reduction (DA SILVA MACHADO, 200). However, a study showed that the bleaching procedure did not affect resin-enamel bond strength, regardless of the waiting time for restoration placement after bleaching (PIMENTEL, 2015).

Other study has shown that when $37 \%$ of carbamide peroxide was used, the bleaching procedure did not interfere with the adhesive system and allowed to perform the restoration immediately after treatment (SILVA, 2017). In spite of that, these results are controversy, since other findings (DA SILVA MACHADO, 2007; VAN DER VYVER, 1997) have demonstrated that adhesion is better after one-two weeks of treatment on the dental substrate.

As the results of the literature are still very conflicting about the waiting time after bleaching treatment, the aim of this in vitro study was to evaluate the influence of post-bleaching of different waiting times using $37 \%$ of carbamide peroxide in the internal bleaching, adhesion to the subjacent enamel and dentin in direct contact with the bleaching agent.

\section{MATERIALS AND METHODS}

Fifteen freshly extracted bovine incisors were kept (stored) in $0.1 \%$ thymol $(\mathrm{pH}=7.0)$. The teeth were submitted to a soft-tissue debriment with periodontal curettes and cleaned with slurry of pumice in a webbed rubber cup in a slow-speed handpiece. Dental crowns were sectioned on the mesio-distal and occlusalcervical directions using a low speed water-cooled diamond saw (Isomet 1000, Buehler, Lake Bluff, IL, USA) to obtain 50-incisal surfaces (enamel) and 50 


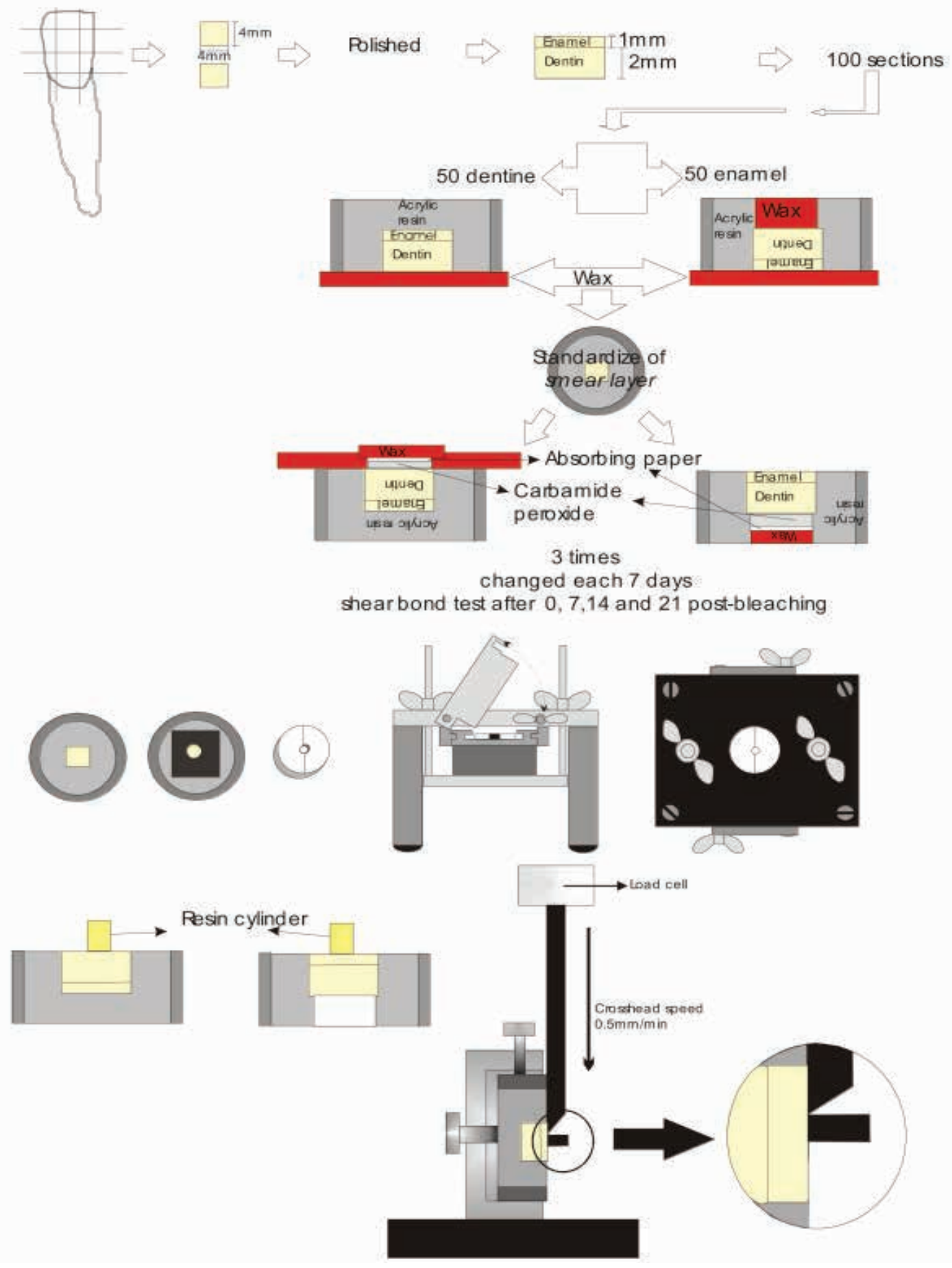

Figure 1. Schematic illustration of specimen preparation and shear bond strength test 
cervical surfaces (dentin). The crows were examined with a stereomicroscope (Nikon Inc. Instrument Group, Melville, NY, USA) at 20x magnification to discard those with structural abnormalities, cracks or fractures.

One hundred specimens were individually embedded in a chemically activated acrylic resin (JET, Classic, São Paulo, SP 05458-001) using polyvinyl chloride rings cylinders $(2.1 \mathrm{~cm}$ diameter and 1.1 $\mathrm{cm}$ height). After resin polymerization, the external dental surfaces (Figure 1) were grounded under water refrigeration in a polishing machine (Politriz DP9U2,Struers A/S, Copenhagen, Denmark) using \#400, \#600 and \#1200-grit grit aluminum oxide papers and a final polishing was performed with 0.50 and 0.03 $\mathrm{mm}$ alumina paste. Specimens were stored in distilled water at $37 \mathrm{C}$ for 24 hours to re-humidify dental tissues.

After 24 hours, the specimens were bleached with $37 \%$ of carbamide peroxide, simulating the technique of non-vital teeth bleaching in the dental office, that is, the bleaching agent remained in direct contact with the dentin according to the manufacturer's instructions. The $37 \%$ carbamide peroxide was placed and, upon it, a thin piece of absorbing paper. Finally, to lock the cavity, a plate of wax was used. The bleaching exchanges were performed 3 times with a 7 day interval between each change, completing in 21 days. During the bleaching, the specimens were stored in artificial saliva at $37 \mathrm{C}$. The amount of bleaching agent used $(0.4 \mathrm{~mL})$ was determined in a preliminary test (Figure 1).

The specimens were then randomly assigned in two groups (dentin and enamel) of equal size $(n=20)$, according to the post-bleaching time proposed to be studied (immediately, 7, 14 and 21 days). During the waiting time and in the restorative procedure, the specimens were stored in artificial saliva at $37 \mathrm{C}$ and the saliva was changed daily.

To perform the adhesive protocol, a bonding site was demarcated and a piece of tape with a 2-mm diameter central hole was attached to the surface of each specimen. This procedure has the objective of delimiting a fixed test surface area and ensuring that the resin composite cylinders would be precisely adhered to the dentin surface. The delimited area of each specimen was etched with $37 \%$ phosphoric acid gel (Etching gel; 3M/ESPE, St. Paul, MN, USA) for 15 $\mathrm{S}$, followed by copiously rinsing with air/water spray during 30 seconds, and the excess water was removed with absorbent paper. In the sequence, two layers of the adhesive system (Single Bond, - 3M Dental Products-St Paul, MN 55144-USA) was applied and light cured for 20 seconds with the light-curing unit (XL3000, 3M Dental Products, USA), with an output of $450 \mathrm{~mW} / \mathrm{cm} 2$, checked with a radiometer (Demetron/ Kerr, Danbury, CT, USA).

After bonding procedure, each specimen was fixed in a clamping metallic device (developed at the Houston Biomaterial Research Center and manufactured at the Precision Workshop at Ribeirão Preto School of Dentistry of the University of São Paulo, Brazil) keeping the dentin surface parallel to a flat surface. A split bisected Teflon (polytetrafluoroethylene) matrix was positioned on the tooth/resin block surface resulting in a cylindrical cavity with a $2 \mathrm{~mm}$ diameter (coincident with the demarcated bonding site) and 4 $\mathrm{mm}$ high. A hybrid composite resin Z250 (Filtek Z250 - 3M Dental Products- St Paul, MN 55144- USA) was inserted into the matrix in three increments and each one was light-cured for $40 \mathrm{~s}$ with one of the ligth source (halogen light or LED). As the matrix cavity was completely filled, the specimen was removed from the clamping device. The matrix was opened and separated, leaving a resin composite cylinder $(2 \mathrm{~mm}$ in diameter, $4 \mathrm{~mm}$ high) adhered to the delimited dentin surface.

After $24 \mathrm{~h}$ storage in distilled water at $37^{\circ} \mathrm{C}$, each cylinder-shaped composite/acrylic resin block was loaded in shear bond in a Universal Testing Machine (MEM 2000, EMIC Ltda, São José dos Pinhais, PR, Brazil), at a crosshead speed of $0.5 \mathrm{~mm} /$ min and a $50 \mathrm{kgf}$ load cell until fracture. Shear bond strengths values were recorded in $\mathrm{kgf}$ and converted into MPa. Fractured specimens were examined with a x40 stereomicroscope (Nikon Inc, Instrument Group, Melville, NY) to assess the failure modes, which were 
classified as: adhesive if the specimen/adhesive interface was occurred; cohesive failure occurred in the material or the substrate with no damage on the interface and finally; mixed if at the same time the interface and the material were involved. Means, standard deviations and medians were calculated, and data were analyzed by Two-way ANOVA and Tukey's test $(=0.05)$.

\section{RESULTS}

Means and standard deviation are in Table 1. Analyzed data showed that the enamel bond strength was statically superior to that of the dentin. It was inferior only to the control group that presented results similar to the 21 days after the bleaching.

By analyzing the substrate separately, it was observed that the bond strength had a significant increase, as the post-bleaching time was longer. This means that the control group was statistically superior to the immediate group, 7 days was similar to the 14 days and all were inferior to the 21-day group. Regarding the dentin group, the control group had higher bond strength than all the waiting times. There was a gradual increase of the bond strength resistance compared the increased waiting time, but did not show similar bond strength to the unbleached substrate.

Regarding the types of fractures, it was observed a predominance of adhesive fracture in all the studied groups.

Table 1. Means and standard deviation of adhesion force to substrate (MPa)

\begin{tabular}{lcc}
\hline Groups & Enamel & Dentin \\
\hline Control & $31.89( \pm 2.39) \mathrm{B}$ & $18.90( \pm 3.64) \mathrm{a}$ \\
$\mathrm{I}$ & $19.07( \pm 2.00) \mathrm{D}$ & $2.22( \pm 0.41) \mathrm{C}$ \\
$7 \mathrm{~d}$ & $24.97( \pm 2.30) \mathrm{C}$ & $3.79( \pm 0.75) \mathrm{C}$ \\
14d & $29.71( \pm 4.89) \mathrm{BC}$ & $5.95( \pm 0.79) \mathrm{b}$ \\
$21 \mathrm{~d}$ & $40.91( \pm 4.75) \mathrm{A}$ & $8.40( \pm 0.87) \mathrm{b}$ \\
\hline
\end{tabular}

${ }^{*}$ Comparing in column - Same letter means statistic similarity

\section{DISCUSSION}

In this research, the bleaching agent had a negative influence of the bond strength on the dental substrates. This is probably due to the residual oxygen concentration (BARCELLOS, 2010; BERGER, 2013; CANNABRAVA, 2014; GAUTHIER, 2005), regardless of whether or not the bleaching agent is directly in contact with the restored surface. It occurs because the active substance of $37 \%$ carbamide peroxide, which is hydrogen peroxide, undergoes decomposition and releases free radicals, which react with the macromolecules responsible for darkening the teeth, such as iron sulfide and hydrogen released (FÉLIZMATOS, 2014). However, hydrogen peroxide remains active in the inner part of pulp chamber and in the dental tubules for some time after bleaching, and possibly, some free radicals may accumulate (BERGER, 2013; CANNABRAVA, 2014) thereby interfering with the polymerization of composite resin and, consequently, reducing the bond strength of this restorative material (DISHMAN, 1994).

Regarding post-bleaching time, it was observed that there was a higher bond strength, especially after 14 days, in which the enamel was similar to the control group. This fact can occur due to the dentin diffusion of products originated by the decomposition of hydrogen peroxide in the restoration surface that inhibited the polymerization of the resin negatively interfering in its adhesion. Therefore, postbleaching time may favor the dissolution of hydrogen peroxide and, with the reduction of the stored local oxygen; there would be less interference in the bond strength of the composite resins (HOSOYA, 2000). Similar results were also observed by Van Der Vyver et al. (1997) and Barkhordar et al. (1997).

In this study, specimens were stored in artificial saliva with fluoride solution during and after bleaching procedure. Fluoride solution may have helped in the remineralization of the specimens and consequently may have improved the results, mainly after 21 days of treatment. The mineral changes may be recovered by ion-containing solutions (BASTING, 2001; LEWINSTEIN, 
2004), in which the superficial remineralization of the enamel through the artificial saliva was possible, or even, to disguise some changes that are occurring in the substrate. However, for dentin, it can be seen that the bleaching material had a greater influence on adhesion. This event can be explained by the possibility that repair of morphological and structural dental changes occur during the time elapsed between bleaching and restorative procedure due to the amount of minerals precipitated in the saliva (BASTING, 2001) is lower than in the enamel, since organic part is also affected. The changes in dentin composition occur due to the decrease of calcium and phosphorus in the post-bleaching procedure, being more significant in the dentin than in the enamel because there is a lower concentration of these minerals in the bleached dentin than in the control group (BERGER, 2014; BASTING, 2014).

As the bleaching agent was placed in contact with the dentin, the hydrogen peroxide decomposition products presented higher concentration in the application area of the bleaching agent. Due to its composition, dentin may be more affected by these materials, since it is less mineralized and has more organic matrix than enamel, in addition to being susceptible to denaturation by carbamide peroxide and hydrogen peroxide that causes morphological changes (BASTING, 2004; BASTING, 2014). The high concentrations of hydrogen peroxide can produce changes in the organic and inorganic components of the dentin, culminating in the reduction of the bond strength between the dental surface and the composite restorations (CANNABRAVA, 2014). Besides, the dentin affected by the action of bleaching agents may lead to a lower microhardness value and, consequently, to a change in the mechanical properties (DE FREITAS, 2002). Another factor observed is that $37 \%$ carbamide peroxide may provide a greater increase in dentin permeability than other bleaching agents of non-vital teeth, being one of the most probable explanations about its better behavior as a bleaching agent (CARRASCO, 200), and therefore, may affect the substrate that did not show comparative improvement with untreated dentin even after 21 days.

As there are conflicts about the interference of the bleaching material on the adhesive systems, as well as the time to restore the post-bleached teeth (BARKHORDAR, 1997; VAN DER VYVER, 1997), further research is needed to optimize the clinical treatment of bleached teeth in the dental office. Therefore, it is suggested to investigate other factors that may interfere in the bond strength of the restorative procedure, such as the type of bleaching material, restorative material and adhesive system used, among others, to find the satisfactory parameters for clinical practice.

\section{CONCLUSION}

On the basis of the results, and within the limitation of an in vitro study, it may be concluded that the $37 \%$ carbamide peroxide negatively influenced the bond strength of the dental substrate mainly in the dentin, and the time intervals after bleaching interfered positively only in the enamel.

\section{ACKNOWLEDGEMENTS}

This study was supported by Foundation for Research Support of the State of São Paulo (FAPESP).

\section{CONFLICT OF INTEREST}

The authors declare no conflict of interest.

\section{REFERENCES}

BARCELLOS, D. C.; BENETTI, P.; FERNANDES, V. V. B.; VALERA, M. C. Effect of carbamide peroxide bleaching gel concentration on the bond strength of dental substrates and resin composite. Operative dentistry, v. 35 , n. 4, p. 463-469, 2010.

BARKHORDAR, R.A.; KEMPLER, D.; PLESH, 0. Effect of nonvital tooth bleaching on microleakage of resin 
composite restorations. Quintessence International, v.28, n.5, p. 341-344, 1997.

BASTING, R. T.; RORIGUES, J. R. A. L.; SERRA, M. C. The effect of $10 \%$ carbamide peroxide bleaching material on microhardnes of sound and demineralized enamel and dentin in situ. Operative Denistryt, v.26, p. 531539, 2001.

BASTING, R. T.; FREITAS, P. M. D.; PIMENTA, L. A. F.; SERRA, M. C. Shear bond strength after dentin bleaching with $10 \%$ carbamide peroxide agents. Brazilian oral research, v. 18, n. 2, p. 162-167, 2004.

BASTING, R. T.; ANTUNES, E. V.; TURSSI, C. P.; DO AMARAL, F. L.; FRANCA, F. M.; FLORIO, F. M. In vitro evaluation of calcium and phosphorus concentrations in enamel submitted to an in-office bleaching gel treatment containing calcium. General dentistry, v. 63, n. 5, p. 52-56, 2014.

BERGER, S. B.; TABCHOURY, C. P.; AMBROSANO, G. M.; GIANNINI, M. Hydrogen peroxide penetration into the pulp chamber and dental permeability after bleaching. General dentistry, v. 61, n. 3, p. e21-5, 2013.

BERGER, S. B.; SOARES, L. E. S.; MARTIN, A. A.; AMBROSANO, G. M. B.; TABCHOURY, C. P. M.; GIANNINI, $M$. Effects of various hydrogen peroxide bleaching concentrations and number of applications on enamel. Brazilian Journal of Oral Sciences, v. 13, n. 1, p. 2227, 2014.

CANNABRAVA, V. P.; FERNANDES, S. L.; CALABRIA, M. P.; MAGALHLÃES, A. C.; ISHIKIRIAMA, S. K.; ATTA, M. T.; WANG, L. Bleaching technique effect on dentin permeability. American Journal of Dentistry, v. 27, n. 3, p. 145-8, 2014.

CARRASCO, L. D.; FRÖNER, I. C.; CORONA, S. A. M.; PÉCORA, J. D. Effect of internal bleaching agents on dentinal permeability of nonvital teeth: quantitative assessment. Dental traumatology, v. 19, n. 2, p. 8589, 2003.

CHNG, H.K.; PALAMARA, J.E.A.; MESSER, H.H. Effects of Hydrogen Peroxide and Sodium Perborate on Biomechanical Properties of Human Dentin. Journal of Endodontics, v.28, n.2, p. 62-67, 2002.
DA SILVA MACHAD0, J.; CÂNDID0, M. S. M.; SUNDFELD, R. H.; DE ALEXANDRE, R. S.; CARDOSO, J. D. The influence of time interval between bleaching and enamel bonding. Journal of Esthetic and Restorative Dentistry, v. 19, n. 2, p. 111-118, 2007.

DE FREITAS, P. M.; BASTING, R.T.; RODRIGUES, J. A.; SERRA, M. C. Effects of two 10\% peroxide carbamide bleaching agents on dentin microhardness at different time intervals. Quintessence International, v. 33, p. 370-375, 2002.

DISHMAN, M.V.; COVEY, D.A.; BAUGHAN, L.W. The effects of peroxide bleaching on composite to enamel bond strength. Dental Materials, v.10, n.1, p. 33-36, 1994.

EIMAR, H.; SICILIANO, R.; ABDALLAH, M. N.; NADER, S. A.; AMIN, W. M.; MARTINEZ, P. P.; CELEMIN, A.; CERRUTI, M.; TAMIMI, F. Hydrogen peroxide whitens teeth by oxidizing the organic structure. Journal of Dentistry, v. 40, n. 2, p. e25-233, 2012.

FÉLIZ-MATOS, L.; HERNÁNDEZ, L. M.; ABREU, N. Dental bleaching techniques; hydrogen-carbamide peroxides and light sources for activation, an update. Mini review article. The open dentistry journal, v. 8 , p. 264, 2014.

FERREIRA, A. F. M.; PEREZ, F. M. D. M. R.; JÚNIOR, F. D. A. L.; DE MOURA, M. D. F. L.; DE SOUSA, F. B. Graded changes in enamel component volumes resulted from a short tooth bleaching procedure. Archives of oral biology, v. 65, p. 52-58, 2016.

GAUTHIER, M. A.; STANGEL, I.; ELLIS, T. H.; ZHU, X. X. Oxygen inhibition in dental resins. Journal of Dental Research, v. 84, p. 725-729, 2005.

HOSOYA, N. H.; COX, C. F.; ARAI, T.; NAKAMURA, J. The walking bleach procedure: an in vitro study to measure microleakage of five temporary sealing agents. Journal of Endodontics, v.26, n.12, p. 716-717, 2000.

KUMAR, A. A.; HARIHARAVEL, V. P.; NARAYANAN, A.; MURALI, S. Effect of protective coating on marginal integrity of nanohybrid composite during bleaching with carbamide peroxide: A microleakage study. Indian Journal of Dental Research, v. 26, n. 2, p. 167, 2015. 
LEWINSTEIN, I.; FUHRER, N.; CHURARU, N.; CARDASH, $\mathrm{H}$. Effect of different peroxide bleaching regimens and subsequent fluoridation on the hardness of human enamel and dentin. Journal of Prosthetic Dentistry, v. 92 , n. 4 , p. $337-342,2004$.

PIMENTEL, A. H.; VALENTE, L. L.; ISOLAN, C. P.; MÜNCHOW, E. A.; PIVA, E.; MORAES, R. R. Effect of waiting time for placing resin composite restorations after bleaching on enamel bond strength. Applied Adhesion Science, v. 3, n. 1, p. 23, 2015.

SPASSER, H. F. A simple bleaching technique using sodium perborate. The New York State Dental Journal, v. 27, p. 332-334, 1961.

SILVA, L.; THEDEI, G. Jr.; MENEZES-OLIVEIRA, M. A.; NOGUEIRA, R. D.; GERALDO-MARTINS, V. Tooth bleaching effects on the adhesive interface of composite restorations. The international journal of esthetic dentistry, v. 12, n. 1, p. 96-106, 2017.

TREDWIN, C. J.; NAIK, S.; LEWIS, N. J.; SCULLY, C. Hydrogen peroxide toothwhitening (bleaching) products: review of adverse effects and safety issues. British Dental Journal, v. 200, p. 371-376, 2006.

VAN DER VYVER, P. J.; LEWIS, S. B.; MARAIS, J. T. The effect of bleaching agent on composite/enamel bonding. The Journal of the Dental Association of South Africa, v.52, n.10, p. 601-603, 1997.

XU, B.; LI, Q.; WANG, Y. Effects of pH values of hydrogen peroxide bleaching agents on enamel surface properties. Operative Dentistry, v. 36, n. 5, p. 554562, 2011.

Recebido em: 14 de agosto de 2017

Aceito em: 19 de outubro de 2017 